\title{
Tobacco Mosaic Virus Subliminal Infection of African Violet
}

\author{
Michael A. Sulzinski ${ }^{1}$, Diane D. Jurkonie ${ }^{2}$, and Christian S. Adonizio ${ }^{3}$ \\ Department of Biology, University of Scranton, Scranton, PA 18510-4625 \\ Additional index words. host range, Saintpaulia ionantha, TMV
}

\begin{abstract}
Wild White' African violet (Saintpaulia ionantha $\mathbf{H}$. Wendl.) was previously reported to be probably immune to tobacco mosaic virus (TMV) infection. In this study, 15 other $S$. ionantha cultivars were mechanically inoculated with $200 \mu \mathrm{g}$ TMV/ml sodium phosphate buffer. Two weeks postinoculation, tissue was harvested and assayed for TMV infection by a) TMV-specific enzyme-linked immunosorbent assay and b) bioassay on the local lesion host, 'Samsun NN' tobacco (Nicotiana tabacum L.). There was evidence of TMV infection in directly inoculated tissue of each of the $15 S$. ionantha cultivars but not in noninoculated tissue or in mock-inoculated control plants. The small amount of virus recovered from inoculated tissue was shown to be the result of de facto viral infection and not the detection of residual inoculum. Postinoculation treatment with ultraviolet light significantly enhanced virus recovery in directly inoculated tissue. These results suggest that $S$. ionantha is not immune to TMV infection and that this host undergoes an asymptomatic subliminal infection by TMV.
\end{abstract}

Very little information is available on virus infections of African violet (Saintpaulia ionantha) or the significance of any virus infection in the commercial cultivation of this species. Holmes (1946) reported that $S$. ionantha demonstrated no increase of virus titer and no manifestation of disease after mechanical inoculation with tobacco mosaic virus (TMV) and concluded that this species is insusceptible to infection. Later, Cheo and Gerard (1971) reported that $S$. ionantha 'Wild White' was probably immune to TMV infection, since there was no detectable recovery of virus under standard conditions and inoculated tissue remained asymptomatic.

The present study was undertaken to perform a more comprehensive investigation of $S$. ionantha susceptibility to TMV infection. This study was undertaken in light of several recent examples where host resistance was reclassified after a further, more detailed examination of activities in asymptomatic, highly resistant plants. For example, Beier et al. (1977) demonstrated that protoplasts from 54 of 55 cowpea (Vigna sinensis Endl.) lines initially thought to be immune to cowpea mosaic virus infection could in fact be infected. Likewise, Sulzinski and Zaitlin (1982) showed that cotton (Gossypum hirsutum L.) and cowpea could support very limited infections after mechanical inoculation with TMV. These very limited asymptomatic virus infections are described as subliminal infections by Bald and Tinsley (1967).

The objective of the present study was to reexamine the interaction between $S$. ionantha and TMV to determine whether plants of this economically important horticultural species could support any level of infection with TMV.

Received for publication 12 Aug. 1993. Accepted for publication 30 Dec. 1993 This project was supported in part by a Howard Hughes Medical Institute grant through the Undergraduate Biological Sciences Education Program and by a faculty research grant from the Univ. of Scranton. We acknowledge the technical assistance of Gerald Negvesky and Bernard Johns. The cost of publishing this paper was defrayed in part by the payment of page charges. Under postal regulations, this paper therefore must be hereby marked advertisement solely to indicate this fact. ${ }^{1}$ Assistant professor.

${ }^{2}$ Former undergraduate student. Present address: Dept. of Plant Pathology, Clemson Univ., Clemson, SC 29634.

${ }^{3}$ Former undergraduate student. Present address: Jefferson Medical College of Thomas Jefferson Univ., Philadelphia, PA 19107.

\section{Materials and Methods}

Mechanical inoculation of plants. Fully expanded leaves from 15 S. ionantha cultivars were dusted with diatomaceous earth and inoculated with $200 \mu \mathrm{g}$ of the $\mathrm{U}_{1}$ strain of TMV per ml of $0.1 \mathrm{M}$ sterile sodium phosphate buffer, $\mathrm{pH}$ 7.0. [This inoculum concentration was chosen because it approximated that used in the original studies on TMV host range (Holmes, 1946)]. Following inoculation, plants were rinsed with a gentle stream of tepid tap water. Mock-inoculated plants were inoculated with buffer. Positive control inoculations were performed by inoculating 'Samsun' tobacco (Nicotiana tabacum L.).

Single leaves of $S$. ionantha 'Blue Mirage' were inoculated with $130 \mu \mathrm{g}$ purified TMV RNA. RNA was prepared from virions by conventional phenol extraction and ethanol precipitation. Positive control inoculations were performed with RNA inoculation of 'Samsun' tobacco. After inoculation, plants were rinsed with a gentle stream of tepid tap water.

Saintpaulia ionantha plants were obtained from Granger Gardens, Medina, Ohio (a gift from the African Violet Society of America, Beaumont, Texas). Virus was obtained from C.P. Romaine, Pennsylvania State Univ.

Virus recovery from extracts. After inoculation, plants were incubated for 14 days under greenhouse conditions (20 to 26C). Directly inoculated and noninoculated tissues were harvested from plants that were inoculated with TMV or TMV RNA or plants that were mock-inoculated. Harvested leaves were surface-treated for $5 \mathrm{~min}$ in $0.01 \mathrm{~N} \mathrm{NaOH}$ to inactivate any residual inoculum and rinsed with sterile distilled water. Bioassay extracts were prepared by grinding tissue in $0.1 \mathrm{~m}$ sterile sodium phosphate buffer, $\mathrm{pH} 7.0$ $(0.5 \mathrm{~g}$ tissue/ml buffer), with a pestle in a chilled mortar. Samples were frozen $(-20 \mathrm{C})$ until analysis by bioassay.

Extracts to be tested with enzyme-linked immunosorbent assay (ELISA) were prepared by grinding $0.1 \mathrm{~g}$ tissue per ml ELISA extraction buffer [2\% (v/v) Tween-20, 2\% (w/v) egg albumin, 2\% $(\mathrm{w} / \mathrm{v})$ polyvinylpyrrolidone, $0.1 \%(\mathrm{v} / \mathrm{v}) 2$-mercaptoethanol, in PBS-Tween [150 mm sodium chloride, $150 \mathrm{~mm}$ sodium phosphate, $0.02 \%$ (v/v) Tween-20)]. Samples were frozen (-20C) until analysis by ELISA.

Ultraviolet (UV) light treatment. Immediately after TMV or mock-inoculation, S. ionantha 'Fashion Flair' plants were placed directly under a 15-W UV lamp (General Electric, Cleveland) at a 
distance of $50 \mathrm{~cm}$. After a 2-, 3-, or 5-h incubation, plants were placed in the greenhouse for the remainder of their 2 week incubation before washing them with $\mathrm{NaOH}$, extraction, and ELISA analysis.

ELISA. Assays were performed with the materials and procedures from a commercially available TMV ELISA assay (Agdia, Elkhart, Ind.) using peroxidase conjugated IgG (anti-TMV) and $\sigma$-phenylenediamine (OPD) substrate. After 13 min of substrate reaction, the reaction was terminated by adding $3 \mathrm{~m}$ sulfuric acid. Microtiter plates were read in a microplate reader (series 750; Cambridge Technology, Watertown, Mass.) to determine optical density at $490 \mathrm{~nm}\left(\mathrm{OD}_{490}\right)$. Each sample was tested in three replicate experiments, with triplicate wells for each ELISA test (n $=9)$.

Positive ELISA controls included extracts from TMV-infected 'Samsun' tobacco. Blank microtiter wells contained only ELISA extraction buffer.

Bioassay. Saintpaulia ionantha extracts were prepared from mock-, TMV RNA-, and TMV-inoculated plants as described above. The extracts were mechanically inoculated onto half-leaves of the hypersensitive host 'Samsun NN'. Each sample was replicate-tested on a minimum of 15 half-leaves and the mean number of local lesions per half-leaf was calculated.

\section{Results and Discussion}

TMV inoculation of S. ionantha. Expanded leaves on each of the $15 S$. ionantha cultivars were mechanically inoculated with TMV. Two weeks postinoculation, there were no visible symptoms or signs of infection on either the directly inoculated tissue or on upper or lower noninoculated tissue. There was no visible difference between the mock- and TMV-inoculated S. ionantha plants. Control 'Samsun' plants inoculated with the same concentration of virus began developing symptoms of TMV infection on upper tissue 5 days postinoculation. At the time of leaf harvest (14 days postinoculation), systemic TMV infection was obvious in TMV-inoculated 'Samsun' plants.

Table 1. Enzyme-linked immunosorbent assay of plant tissue extracts from mock- and tobacco mosaic virus (TMV)-directly inoculated Saintpaulia ionantha.

\begin{tabular}{lcc}
\hline Cultivar & $\begin{array}{c}\text { Mock } \\
\text { inoculated } \\
\left(\mathrm{OD}_{490}\right)\end{array}$ & $\begin{array}{c}\text { TMV } \\
\text { inoculated } \\
\left(\mathrm{OD}_{490}\right)\end{array}$ \\
\hline Blue Mirage & $0.002^{\mathrm{z}}(0.002)^{\mathrm{y}}$ & $0.052^{* *}(0.013)$ \\
Coralette & $0.010(0.016)$ & $0.168^{* *}(0.043)$ \\
Crystallaire & $0.002(0.002)$ & $0.041^{* *}(0.003)$ \\
Disco Doll & $0.008(0.010)$ & $0.103^{* * *}(0.028)$ \\
Fashion Flair & $0.001(0.001)$ & $0.077^{* *}(0.006)$ \\
Gilded Edge & $0.008(0.010)$ & $0.057^{* *}(0.029)$ \\
Kathy Gee & $0.001(0.000)$ & $0.048^{* *}(0.027)$ \\
Lavender Charm & $0.004(0.001)$ & $0.062^{* * *}(0.023)$ \\
Masayo & $0.001(0.001)$ & $0.023^{* * *}(0.007)$ \\
Orchid Glory & $0.002(0.003)$ & $0.142^{* *}(0.009)$ \\
Rascal Dazzle & $0.001(0.001)$ & $0.030^{* *}(0.011)$ \\
Ruby Tuesday & $0.002(0.001)$ & $0.122^{* *}(0.048)$ \\
Startler & $0.003(0.002)$ & $0.081^{* * *}(0.032)$ \\
Utako & $0.001(0.002)$ & $0.226^{* * *}(0.033)$ \\
White Cascade & $0.004(0.005)$ & $0.029^{* *}(0.006)$
\end{tabular}

${ }^{\mathrm{z}}$ Mean $\mathrm{OD}_{490}$ of samples, $\mathrm{n}=9$.

$\mathrm{y}_{\mathrm{SD}}$.

${ }^{* *}$ Significant at $P=0.01$, Student $t$ test.
ELISA. A cut-off point for ELISA positivity was defined using the Student $t$ distribution at a $99 \%$ confidence level. For each of the 15 cultivars, the ELISA values from virus-inoculated tissue were compared with the respective mock-inoculation values to determine positivity. All 15 cultivars generated a positive ELISA signal $(P=0.01$, Student $t$ test $)$ from extracts of directly inoculated tissue (Tables 1 and 2). There were differences in the intensity of ELISA signals between $S$. ionantha cultivars, but it would be difficult to assess whether there is biological significance in these differences.

To demonstrate that these weakly positive ELISA signals were the result of de facto TMV infection and not residual inoculum on inoculated leaves, an experiment was devised to test the efficacy of the $\mathrm{NaOH}$ wash of inoculated tissue. TMV-inoculated $(200 \mu \mathrm{g}$ $\mathrm{TMV} / \mathrm{ml}$ ) $S$. ionantha tissue was harvested $1 \mathrm{~h}$ postinoculation, surface-treated with $\mathrm{NaOH}$, and rinsed, and the extract was analyzed by ELISA (Table 3). The ELISA signal from the washed sample was very low (mean $\mathrm{OD}_{490}=0.003$ ), a result indicating that washing effectively eliminated any signal from residual inoculum. There was no significant difference $(P=0.01)$ between the $\mathrm{NaOH}$-washed specimens and mock-inoculated samples. Thus, at $1 \mathrm{~h}$ postinoculation, the signal from virus-inoculated, washed tissue was at the background level for ELISA.

The demonstration that all residual inoculum could be effectively removed at $1 \mathrm{~h}$ postinoculation is significant. Since the viability of any residual inoculum will decrease with time postinoculation, the same wash treatment on tissue harvested 2 weeks later should remove any lesser amount of residual inoculum still remaining at that time.

Consequently, any ELISA signal that was generated in incubated tissue washed before extraction was the result of virus

Table 2. Enzyme-linked immunosorbent assay of plant tissue extracts from directly inoculated Nicotiana tabacum 'Samsun'.

\begin{tabular}{lcc}
\hline \hline Dilution & $\mathrm{OD}_{490}$ \\
\hline \multirow{3}{*}{ None } & & \\
$1: 10$ & & $1.438^{\mathrm{z}}(0.082)^{\mathrm{y}}$ \\
$1: 100$ & & $1.007(0.064)$ \\
$1: 1000$ & & $0.253(0.035)$ \\
& & $0.033(0.012)$
\end{tabular}

None

$0.003(0.003)$

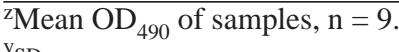

$\mathrm{y}_{\mathrm{SD}}$.

Table 3. Efficacy of $\mathrm{NaOH}$ wash to remove tobacco mosaic virus (TMV) inoculum. ${ }^{\mathrm{z}}$

\begin{tabular}{lc}
\hline \hline Enzyme-linked immunosorbent assay & $\mathrm{OD}_{490}$ \\
\hline Mock-inoculated tissue, $-\mathrm{NaOH}$ & $0.002^{\mathrm{y}}(0.001)^{\mathrm{x}}$ \\
TMV-inoculated tissue ${ }^{\mathrm{w}},-\mathrm{NaOH}$ & $0.403(0.038)$ \\
TMV-inoculated tissue, $+\mathrm{NaOH}^{\mathrm{v}}$ & $0.003(0.001)$ \\
Bioassay & Lesions/leaf \\
\hline Mock-inoculated tissue, $-\mathrm{NaOH}$ & $0^{\mathrm{u}}(0)^{\mathrm{x}}$ \\
TMV-inoculated tissue, $-\mathrm{NaOH}$ & $19.8(12.1)$ \\
TMV-inoculated tissue, $+\mathrm{NaOH}$ & $0(0)$ \\
\hline
\end{tabular}

${ }^{\mathrm{z}}$ Directly inoculated tissue was collected at $1 \mathrm{~h}$ postinoculation

${ }^{y}$ Mean $\mathrm{OD}_{490}$ of samples, $\mathrm{n}=9$.

${ }^{x_{S D}}$.

${ }^{\mathrm{w}}$ Concentration $=200 \mu \mathrm{g} \mathrm{TMV} / \mathrm{ml}$.

v'Soaked in $0.01 \mathrm{~N} \mathrm{NaOH}$ for 5 min and rinsed with sterile distilled water. 'Mean number of lesions per inoculated Nicotiana tabacum 'Samsun NN' leaf. 
replication. To provide even further evidence that the ELISA signal did not result from residual inoculum, 'Blue Mirage' was inoculated with TMV-RNA, incubated, and its tissue harvested 2 weeks postinoculation. When the extracts were analyzed by ELISA, a positive signal (mean $\mathrm{OD}_{490}=0.155$ ) was detected in tissue inoculated with RNA, but not in mock-inoculated tissue (mean $\left.\mathrm{OD}_{490}=0.005\right)$ (Table 4). This result is significant because, in this case, no TMV antigen was applied to the inoculated tissue, and any ELISA signal had to be generated by newly replicated virions.

To address the possibility that there were inhibitors in $S$. ionantha extracts that minimized the ELISA reaction, healthy $S$. ionantha extracts were spiked in vitro with purified virus, and the ELISA signal was compared to that from extraction buffer spiked in the same way. There was no difference $(P=0.005)$ between the spiked $S$. ionantha extract (mean $\left.\mathrm{OD}_{490}=0.597\right)$, and the spiked extraction buffer (mean $\left.\mathrm{OD}_{490}=0.594\right)$. This finding indicated that the minimal ELISA signal from $S$. ionantha was truly indicative of a low virus concentration and not merely the result of ELISA inhibition by $S$. ionantha extracts.

To determine the effect of lower inoculum concentration on the subliminal infection of $S$. ionantha, TMV inoculations were also carried out with inoculum at $2.5 \mu \mathrm{g} \mathrm{TMV} / \mathrm{ml}$ phosphate buffer. This concentration was chosen because it was in the range ( 0.1 to $10.0 \mu \mathrm{g}$ virus/ml) used by Cheo (1970) in his studies on TMV subliminal infection of cotton. When tissue inoculated at the lower inoculum concentration was analyzed by ELISA, there was no difference between virus-inoculated tissue and the mock-inoculated controls $(P=0.05)$.

Bioassay. Extracts from inoculated $S$. ionantha plants were tested for infectivity by inoculating extracts onto 'Samsun NN'. The bioassay results were consistent with the ELISA data; there was evidence of a small amount of virus recoverable from each of the $S$. ionantha cultivars tested (Table 5). Given that the extracts of cultivars generated means of 0.2 to 0.9 local lesions per half-leaf, the infectivity detected is well below the useful range (10 to 100 lesions per leaf) for statistical analysis (Best, 1937; Matthews, 1992), even statistical analysis involving logarithmic transformation (Kleczkowski, 1949). The data presented in Table 5 are interpreted to reflect a qualitative, not quantitative, recovery of minimal infectivity from inoculated tissue.

Extracts from mock-inoculated negative controls produced no local lesions; TMV inoculated 'Samsun' positive control extracts generated $>200$ lesions per leaf when tested by bioassay.

A control experiment was designed to determine whether the small number of local lesions produced from Saintpaulia ionantha extracts represented infectivity from residual inoculum. Inoculated tissue was surface-treated with $\mathrm{NaOH}$ and rinsed with distilled water before extraction. Our data (Table 3) demonstrate the efficacy of this treatment, which established that any local lesions produced from the bioassay of $S$. ionantha extracts were the result of bona fide TMV infection and not residual inoculum.

Analysis of noninoculated tissue. To determine if virus could be detected in noninoculated tissue, noninoculated upper and lower leaves from 'Fashion Flair' plants inoculated with virus were harvested 2 weeks postinoculation. When these leaves were extracted and analyzed by ELISA, the mean of $\mathrm{OD}_{490}$ values was 0.004 for upper noninoculated tissue and 0.005 for lower noninoculated tissue. There was no statistical difference $(P=0.01)$ between these ELISA values and those from mock-inoculated extracts. Thus, there was no indication of virus movement to noninoculated tissue, even though directly inoculated leaves from the same cultivar generated a positive signal $(P=0.01)$. This result suggests that the limited amount of infection that occurred was
Table 4. Enzyme-linked immunosorbent assay of tissue directly inoculated with tobacco mosaic virus (TMV) RNA. ${ }^{\mathrm{z}}$

\begin{tabular}{lcc}
\hline \hline $\begin{array}{l}\text { Host and } \\
\text { time } \\
\text { postinoculation }\end{array}$ & $\begin{array}{c}\text { Mock } \\
\text { inoculated } \\
\left(\mathrm{OD}_{490}\right)\end{array}$ & $\begin{array}{c}\text { TMV RNA } \\
\text { inoculated } \\
\left(\mathrm{OD}_{490}\right)\end{array}$ \\
\hline $\begin{array}{l}\text { Saintpaulia ionantha } \text { Blue Mirage } \\
1 \mathrm{~h}\end{array}$ & $\begin{array}{c}0.005^{\mathrm{y}}(0.002)^{\mathrm{x}} \\
0.005(0.002)\end{array}$ & $0.003(0.001)$ \\
$\begin{array}{l}\text { N weeks } \\
\text { Nicotiana tabacum Samsun }\end{array}$ & $0.155^{* *}(0.009)$ \\
$1 \mathrm{~h}$ & $0.005(0.002)$ & $0.006(0.003)$ \\
2 weeks & $0.007(0.005)$ & $1.106(0.032)$ \\
\hline
\end{tabular}

Inoculation with $130 \mu \mathrm{g}$ TMV RNA

${ }^{\mathrm{y}}$ Mean $\mathrm{OD}_{490}$ of samples, $\mathrm{n}=9$.

${ }^{\mathrm{x}_{\mathrm{SD}} \text {. }}$

${ }^{* * *}$ Significant at $P=0.01$, Student $t$ test.

Table 5. Bioassay analysis of plant tissue extracts.

\begin{tabular}{lcc}
\hline \hline & \multicolumn{2}{c}{ No. of lesions } \\
\cline { 2 - 3 } Species and & $\begin{array}{c}\text { Mock } \\
\text { inoculated }\end{array}$ & $\begin{array}{c}\text { TMV } \\
\text { inoculated }\end{array}$ \\
\hline Saintpaulia ionantha & & $0.6^{\mathrm{z}}(0.8)^{\mathrm{y}}$ \\
Blue Mirage & 0 & $0.8(1.0)$ \\
Coralette & 0 & $0.6(0.9)$ \\
Crystallaire & 0 & $0.5(0.9)$ \\
Disco Doll & 0 & $0.8(1.1)$ \\
Gilded Edge & 0 & $0.6(1.0)$ \\
Kathy Gee & 0 & $0.4(0.9)$ \\
Masayo & 0 & $0.9(1.5)$ \\
Orchid Glory & 0 & $0.5(0.9)$ \\
Rascal Dazzle & 0 & $0.2(0.4)$ \\
Ruby Tuesday & 0 & $0.3(0.6)$ \\
Startler & 0 & $0.5(0.8)$ \\
Utako & 0 & $0.4(0.7)$ \\
White Cascade & 0 & $0.6(1.0)$ \\
Wonderland & 0 & $>200$ \\
Nicotiana tabacum (positive control) & &
\end{tabular}

${ }^{\mathrm{z}}$ Mean number of lesions per inoculated N. tabacum 'Samsun NN' half-leaf.

$\mathrm{y}_{\mathrm{SD}}$.

Table 6. Effect of ultraviolet (UV) irradiation on virus recovery in Saintpaulia ionantha 'Fashion Flair'. ${ }^{\text {. }}$

\begin{tabular}{lccc}
\hline \hline \multirow{2}{*}{$\begin{array}{l}\text { Inoculation and } \\
\text { UV exposure }\end{array}$} & \multicolumn{2}{c}{ Tissue } \\
\cline { 2 - 4 }$(\mathrm{h})$ & $\begin{array}{c}\text { Directly } \\
\text { inoculated }\end{array}$ & Upper & Loninoculated \\
\cline { 2 - 4 } Mock, 0 & $0.001^{\mathrm{z}}(0.001)^{\mathrm{y}}$ & $0.001(0.001)$ & $0.002(0.002)$ \\
TMV, 0 & $0.077(0.006)$ & $0.004(0.003)$ & $0.005(0.001)$ \\
TMV, 2 & $0.110^{\text {*** }}(0.014)$ & $0.001^{\mathrm{NS}}(0.002)$ & $0.006^{\text {NS }}(0.005)$ \\
TMV, 3 & $0.238^{* * *}(0.014)$ & $0.005^{\text {NS }}(0.002)$ & $0.005^{\text {NS }}(0.005)$ \\
TMV, 5 & $0.406^{* * *}(0.030)$ & $0.001^{\text {NS }}(0.001)$ & $0.002^{\text {NS }}(0.002)$
\end{tabular}

${ }_{\mathrm{z}}^{\mathrm{Z}}$ Mean of $\mathrm{OD}_{490}$ scores.

$\mathrm{y}_{\mathrm{SD}}$.

Ns,*** Nonsignificant or significant at $P=0.01$, respectively, when compared to same tissue source with no UV treatment using Student $t$ test.

confined to directly inoculated $S$. ionantha leaves.

Effect of $U V$ light on extent of infection. There are several examples where virus recovery has been enhanced by UV irradia- 
tion of virus-inoculated protoplasts (Maekawa et al., 1981). Virus-inoculated S. ionantha tissue was treated with UV light to determine whether the otherwise minuscule virus recovery could be enhanced by this external stress. 'Fashion Flair' plants were exposed to UV light as described, and directly inoculated and noninoculated tissues were harvested for ELISA analysis. The results (Table 6) indicate that the recovery of newly replicated virus is indeed enhanced in directly inoculated tissue after a 2-, 3-, or 5 -h postinoculation treatment and 2 -week greenhouse incubation. $\mathrm{UV}$ treatments for longer periods were overtly harmful to plant tissue.

Noninoculated upper and lower tissue from plants treated with UV light was also analyzed by ELISA, but there was no detectable virus recovery from this tissue. There was no difference in the ELISA signal compared to the mock-inoculated control $(P=0.05)$ (Table 6). Thus, even though virus recovery was stimulated in directly inoculated tissue, there is still no indication of virus movement into noninoculated tissue.

Saintpaulia ionantha was previously reported to be probably immune to TMV infection (Cheo and Gerard, 1971). Based on the results of ELISA and bioassay analysis of $S$. ionantha extracts after mechanical inoculation, it seems that $S$. ionantha sustains an asymptomatic, low-level subliminal infection after mechanical inoculation with TMV.

The small amount of virus recovered from inoculated tissue also may have been the result of protection of inoculum by a wound response without replication; however, this is unlikely based on data from initial experiments. To determine the time course of replication, samples were also collected at 7 days postinoculation from four other cultivars (Orchid Glory, Blue Mirage, Kathy Gee, and Lavendar Charm). There was no significant difference $(P=$ $0.005)$ between the ELISA signals of the 7-day postinoculation samples and the 1-h postinoculation samples. If there had been protection of applied inoculum by wound response, the signal from the 7-day ELISA sample should have been greater than or equal to that of 14-day samples.

Since such a small amount of virus was recovered from these plants after inoculation, it was necessary to demonstrate that these minimal signals did not result from the detection of residual inoculum. Data presented in Table 3 validate the efficacy of our treatment to remove any residual inoculum. While there was a considerable amount of residual viral inoculum detected on unwashed tissue, residual inoculum could not be detected by ELISA or bioassay after $\mathrm{NaOH}$ treatment. Moreover, data presented in Table 3 demonstrate that infection occurs even when viral RNA is used as inoculum, effectively eliminating the possibility of residual antigens or infectivity.

Cheo and Gerard (1971) originally classified S. ionantha as probably immune to TMV infection based on their inability to recover any virus after mechanical inoculation. One difference between our study and their study is that we used a more-concentrated inoculum. In fact, when we used a lower concentration of virus, we also were unable to detect TMV infection. The apparent necessity for high inoculum concentration could reflect the extremely hydrophobic nature of the $S$. ionantha leaf surface. In this species, there is an extraordinarily thick cuticle covered with epicuticular wax. Both are barriers to virus infection (Matthews, 1992), especially if involvement of ectodesmata is required for infection. Possibly, with lower concentrations of inoculum, the number of infected cells is exceedingly small and antigen is well below the ELISA detection limit, especially if $S$. ionantha was actively preventing cell-to-cell movement of infectivity (see below). More-sensitive detection assays exploiting polymerase chain reaction amplification may be useful in detecting evidence of infection after low-dose inoculation.

The observation that postinoculation UV light treatment of inoculated tissue increases virus recovery suggests that the extreme resistance normally exhibited by $S$. ionantha is sensitive to environmental conditions. Maekawa et al. (1981) hypothesized that UV enhancement of brome mosaic virus multiplication in radish (Raphanus sativus L.) and turnip (Brassica rapa L.) protoplasts was the result of decreased production of cellular polypeptides normally inhibitory to virus replication. In $S$. ionantha, a host protein may normally interact with or prevent the synthesis of TMV $30 \mathrm{kD}$ movement protein, thus confining infectivity to initially infected cells. If synthesis of such a putative host protein were blocked by UV light, short-distance viral movement might occur, leading to enhanced virus recovery in directly inoculated tissue. If this scheme were valid, long-distance transport would remain unaffected by UV light.

Whatever the mechanism, the observation of enhanced virus recovery provides even stronger evidence that $S$. ionantha is not immune to TMV infection and can support virus infection to varying degrees, depending on environmental conditions.

\section{Literature Cited}

Bald, J.G. and T.W. Tinsley. 1967. A quasi-genetic model for plant-virus host ranges. I. Group reactions within taxonomic boundaries. Virology 31:616-624.

Beier, H., D.J. Siler, M.L. Russell, and G. Bruening. 1977. Survey of susceptibility to cowpea mosaic virus among protoplasts and intact plants from Vigna sinensis lines. Phytopathology 67:917-921.

Best, R.J. 1936. The quantitative estimation of relative concentration of the viruses of ordinary and yellow tobacco mosaics and of tomato spotted wilt by the primary lesion method. Austral. J. Expt. Biol. Medical Sci. 15:65-79.

Cheo, P.C. 1970. Subliminal infection of cotton by tobacco mosaic virus. Phytopathology 60:41-46.

Cheo, P.C. and J.S. Gerard. 1971. Differences in virus-replicating capacity among plant species inoculated with tobacco mosaic virus. Phytopathology 61:1010-1012.

Holmes, F.O. 1946. A comparison of the experimental host ranges of tobacco etch and tobacco mosaic viruses. Phytopathology 36:645-659.

Kleczkowski, A. 1949. The transformation of local lesion counts for statistical analysis. Ann. Applied Biol. 36:139-152.

Maekawa, K., I. Furusawa, and T. Okuno. 1981. Effects of actinomycin $\mathrm{D}$ and ultraviolet irradiation on multiplication of brome mosaic virus in host and non-host cells. J. Gen. Virol. 53:353-356.

Matthews, R.E.F. 1992. Plant virology. 3rd ed. Academic Press, New York.

Sulzinski, M.A. and M. Zaitlin. 1982. Tobacco mosaic virus replication in resistant and susceptible plants: In some resistant species virus is confined to a few initially infected cells. Virology 121:12-19. 